\title{
WNT5B wt Allele
}

National Cancer Institute

\section{Source}

National Cancer Institute. WNT5B wt Allele. NCI Thesaurus. Code C127922.

Human WNT 5B wild-type allele is located in the vicinity of 12p13.3 and is approximately

$117 \mathrm{~kb}$ in length. This allele, which encodes protein Wnt-5b, is involved in G proteincoupled receptor signaling. 